\title{
Entrepreneurial Ecosystem, Entrepreneurial Activity and Economic Performance
}

\author{
Kanza Sohail \\ kanzasohail1@gmail.com
}

\begin{abstract}
Abstrak- In this research, we have empirically tested the impact of Entrepreneurial Framework Conditions (EFC) on entrepreneurial activity and ultimately on economic growth of a nation. In our sample all the 54 countries participating in the GEM study in 2017 are taken. $67.8 \%$ of the world's population and $86.0 \%$ of the world's GDP is represented by the economies included in GEM 2017 . The entrepreneurial ecosystem is captured through 12 EFCs used in the GEM model that includes: Financial environment, government policy of support and relevance, government policy of taxes and bureaucracy, government programs, entrepreneurial education at school stage and post school stage, $R \& D$ transfer, commercial and legal infrastructure, internal market dynamics, access to physical infrastructure, and social and cultural norms. The impact of these EFCs and their significance in creating entrepreneurial activity (TEA) in a nation is analyzed using OLS estimation technique with TEA as dependent variable. Secondly, the impact of entrepreneurial activity (TEA) on economic growth ( $\Delta$ GDP) is estimated using OLS regression model with control variables such as global competitiveness index (GCI) and Gross national income per capita, expressed in purchasing power parity (GNIC). The results suggest that entrepreneurship education at post school stage, entry burdens and cultural and social norms are significant framework conditions that support entrepreneurial activity, while $R \& D$ transfer, internal market dynamics and commercial and legal infrastructure hinders the process of entrepreneurship. Furthermore, TEA is significantly contributing to the economic growth of factor driven and efficiency driven economies.
\end{abstract}

Keywords- Entrepreneurship, Entrepreneurial framework conditions, GEM model, economic growth, macroeconomic analysis.

\section{INTRODUCTION}

Entrepreneurship is the buzz word of the day. All the nations weather developing or developed have recognized the importance of entrepreneurship and innovation as an agent of economic growth and poverty alleviation(Bruton, Ketchen, \& Ireland, 2013). Entrepreneurship is also a means of generating employment especially for the youth, women and people from rural areas (Bullough, De Luque, Abdelzaher, \& Heim, 2015). With saturated job market, and the huge youth population governments all across the world along with higher education commissions have aimed at proliferation of entrepreneurship development programs, incubation centers, startup competitions. The purpose is to increase the supply of entrepreneurs and improve their chances of success (Brown \& Hanlon, 2016). GEM data base captures 12 of these entrepreneurship support conditions as entrepreneurial framework conditions (EFCs) on national level.

The sole purpose of supporting entrepreneurship is to increase economic growth. Reynold (2005) have proposed GEM model arguing that along with established firm's activity, nascent and budding entrepreneurs significantly contribute to the economic growth of a country. Literature suggests that entrepreneurship can support economic growth through three important channels: innovation creation, innovation diffusion, and competition (Bosma, Sanders, \& Stam, 2018; Wennekers \& Thurik, 1999).
Innovation creation means that variety could be increased by introducing new knowledge in the economy(Metcalfe, 2004; J. Schumpeter, 1942). The second important channel is the diffusion of this new knowledge by entrepreneurs who are opportunity seekers and fill the market gaps (Kirzner, 1997). Finally, competition amongst the entrepreneurs will lead to economic growth(Aghion, Blundell, Griffith, Howitt, \& Prantl, 2006; Kirzner, 2015). Although many researchers have established the fact that entrepreneurs are important for growth but causality between entrepreneurial activity and economic growth has not yet been established (Carree, Van Stel, Thurik, $\&$ Wennekers, 2007).

Although there is huge upsurge of these support conditions but the current study will explore the significance of these framework conditions on the entrepreneurial activity and will analyze the impact of entrepreneurial activity on economic growth by using 2017 GEM data for 54 countries at different development stage.

Overall this study has contributed to the available literature, the empirically tested significance of the 12 EFCs included in the GEM model. This will assist the policy makers of countries prioritizing entrepreneurship to identify the conditions that most significantly can increase the entrepreneurial activity depending upon their development stage. Though there are few studies that tested the impact of EFCs on entrepreneurial activity (Hechavarría \& Ingram, 2018; 
Levie \& Autio, 2011) but since all the EFCs represents structural changes that need time to create an impact, the available studies fail to significantly relate most of these Entrepreneurial framework conditions on entrepreneurial activity. We expect that recent data will be able to capture the impact of the not so old explosion of these structural changes and thus provide a better guidance. Secondly there has been no holistic study that captures the simultaneous testing of entrepreneurial activity (based on these entrepreneurial framework condition) on economic growth. Following are the specific research objectives of this study:

- To analyze the impact of entrepreneurial framework conditions in different countries on the level of its entrepreneurial activity.

- To analyze the impact of entrepreneurial activity on economic growth by controlling for development stage in factor driven, efficiency driven, and innovation driven economies.

\section{The GEM model}

II. LITERATURE REVIEW

In 1997, Paul Reynolds proposed the GEM Model based on the idea by Michael Hay for the world Enterprise Index. The purpose was to suggest an equivalent for enterprise and entrepreneurship of IMD's World Competitiveness Yearbook and the World Economic Forum's Global Competitiveness Index (Levie \& Autio, 2008). Paul Reynolds desired to provide something that accompanied the Global Competitiveness Model, in the reports produced by the World Economic Forum at the time. He added the importance of entrepreneurs and startups along with large established firms in the economic development of any nation (P. D. Reynolds, 2012).

The GEM model differentiates between entrepreneurial activity and established business activity by explaining the different factors influencing each type of activity, although both are interrelated (see figure 1). In this paper we restrict ourselves only on the Entrepreneurial activity side and establishment of new firms and finally their impact on the economic growth (figure 1, boxed portion). Thus drawing on the GEM conceptual model(P. Reynolds et al., 2005), we focus on EFC component only. This subset of the GEM model apprehends those conditions that assist or hinder the entrepreneurial activity in a country (Baumol, 1990; North, 1994; Sobel, 2008). It has been argued that country level entrepreneurial activity not only depends upon individual capacities and actions but also the institutional incentives (Welter, 2011). Moreover
GEM model argues the growth in economic activity due to increased entrepreneurial activity.

In the current study, we propose to empirically test the GEM model underlying assumptions about influence of EFCs on entrepreneurial activity and then impact of entrepreneurial activity on economic growth. The next sections will explain the theoretical grounding of these relationships.

\section{Entrepreneurial framework conditions and Entrepreneurial activity}

The following sub sections will discuss 12 EFCs in the GEM model and its impact on entrepreneurial activity as explained by the literature to date:

\section{Financial environment}

The available literature suggests that access to finance is the most important regulator that controls the entrepreneurial activity in an ecosystem. As a rule, some upfront investment is required to kick off an entrepreneurial activity and even that is supported by initial theories of entrepreneurship including Schumpeter, who accepted the importance of bank credit availability or private equity providers to support entrepreneurship (Schumpeter, 1934). Thus the entrepreneurial activity in any country depends upon the sophistication of credit and lending systems (Leibenstein, 1968). These researches have led policy makers to include access to finance as an important object of entrepreneurship policy. It is equally recognized by the entrepreneurs themselves by reporting the unavailability of finance a major barrier to starting a new business (Choo \& Wong, 2006; Kouriloff, 2000; Robertson, Collins, Medeira, \& Slater, 2003; Volery, Doss, Mazzarol, \& Thein, 1997). The earlier researches also suggest the difference between routine financing and entrepreneurial credit requirements and consequently these two types of financing should be considered separately in any policy model (Leibenstein, 1968).

\section{Government policy: Support and relevance}

Government policy of support and relevance reflects the emphasis of government on the broad policy interest of innovation and venturing (Stevenson $\&$ Lundström, 2007). There is a general consensus that entrepreneurship is a national phenomenon that can be addressed by policy makers at national and regional levels, and increased awareness and efforts of policy maker to positively influence entrepreneurial activity are widely acknowledged (Audretsch, Grilo, \& Thurik, 2007). Most of the innovative driven economies have government policies that support entrepreneurship and thus shows the importance of policy intervention in the change of economic activity (Storey, 2003). The GEM 
model under study, does not capture specific government policies in favor of entrepreneurship, but instead measures the general prioritization of entrepreneurship as a national objective in context of supporting and motivating entrepreneurs to develop the economy (Acs, Arenius, Hay, \& Minniti, 2004; Leibenstein, 1968; Levie \& Autio, 2011). There is ambiguous impact of government support policies of entrepreneurship in the empirical literature, as some studies support the argument (McMullen, Bagby, \& Palich, 2008), while others show no evidence of such support (Levie \& Autio, 2011).

\section{Government policies: taxes and bureaucracy}

Government policies regarding taxation, bureaucracy are common barriers towards entrepreneurial activity (Acs, Desai, \& Hessels, 2008). Empirical research suggests two possible ways in which these regulations and policies impact the entrepreneurial process. First, the prolong and cumbersome regulations and delays in the venturing process may increase the time of startup (Klepper \& Sleeper, 2005) and also lead to missed opportunity (Mullins \& Forlani, 2005). Secondly, complying with regulations, also increases the cost of venturing into new business. Tax policies play a crucial role in incentivizing entrepreneurial activity and removes the barrier of this additional financial cost burden (Keuschnigg \& Nielsen, 2004). Although some studies have also reported higher tax rates linked with higher level of entrepreneurial activity, as venturing allows the entrepreneur to under report the profits and thus save on taxes, which is not possible in case of wages (Blau, 1987).

\section{Government Programs}

Government programs refer to the nurturing of the entrepreneurs through providing professional services advisors, accountants, bankers, lawyers, and consultants (Clarysse \& Bruneel, 2007; Fischer \& Reuber, 2003). These government programs are based on the idea of filling the gap in resources and competencies of entrepreneurs. These services are provided at subsidized rate through government trade chambers or incubation and acceleration programs thus minimizing the transaction cost and enhancing the human capital (Keuschnigg \& Nielsen, 2004; Shane \& Cable, 2002).

Entrepreneurial Education - at school stage and post school

Entrepreneurial education and training is a widely researched and implemented program by the governments and private NGOs in order to foster entrepreneurial activity in a country. The entrepreneurial education at school stage helps develop the mindset of the youth to take up entrepreneurship as a career option (Peterman \& Kennedy, 2003). Whereas entrepreneurship education and training at post school stage is focused to enhance the entrepreneurial activity through opportunity recognition and exploitation. This kind of training works on improving the cognitive capabilities of an individual and thus sharpening the skills to analyze and observe the surroundings for opportunity recognition (DeTienne \& Chandler, 2004). Moreover these training and education programs also help budding entrepreneurs to obtain instrumental business skills required to start and manage a business (Honig, 2004). Previous studies on entrepreneurship education and training has been unsuccessful to provide much evidence that the skills taught are actually required by future entrepreneurs (Edelman, Manolova, \& Brush, 2008) or that help generate more or better entrepreneurs (Martin, McNally, \& Kay, 2013). Only a few empirical findings are available that favor the impact of entrepreneurship education design. While, most of the relationships between entrepreneurship education and the real world remain underspecified (Vanevenhoven, 2013), leaving researchers and educators relying too much on the theoretical framework.

\section{$R \& D$ Transfer}

Schumpeter and Krizner supported innovation and entrepreneurship as engine of economic growth (Kirzner, 1997; J. Schumpeter, 1942) . This theory was further extended by Knowledge spill-over theory of entrepreneurship that proposes the fact that venturing and new business activity capitalizes on the unutilized knowledge sources of other companies (Acs et al., 2004). This theory argued that entrepreneurs are able to exploit the knowledge spillovers because new asymmetric and uncertain knowledge attracts the risk taking and opportunity identifier entrepreneurs (Audretsch \& Lehmann, 2005). Alertness and discovery are the two cognitive skills that are required to reveal and connect the unused knowledge created by incumbents (Acs \& Varga, 2005). Countries with low cost of R\&D transfer are likely to have higher levels of entrepreneurial activity where this process is slow and costly (Markman, Gianiodis, Phan, \& Balkin, 2004).

\section{Commercial and Legal Infrastructure:}

Commercial and legal service embraces all those services that are fundamental for entrepreneurs and new firm formation. These services include availability of suppliers, consultants, and financial service providers, legal consultants that sets an 
ecosystem for the entrepreneurs (Levie \& Autio, 2008).

The presence of these supporting services in the ecosystem, allows the entrepreneurs to concentrate on the innovation side of the business by taking care of the peripheral business functions (Suzuki, Kim, \& Bae, 2002). Legal services are not only important throughout the business life but are most crucial at the initial stage (Ruef, 2005) and availability of such services reduces the entry barriers for nascent entrepreneurs(Brenner, 1992; Lee, Yamakawa, Peng, \& Barney, 2011).

\section{Internal market dynamics}

Market dynamics is one of the macroeconomic variable (Klepper \& Sleeper, 2005) that again make use of the risk taking ability of entrepreneurs. This variable has been recognized by earlier theories as a motivating factor in entrepreneurial activity (Kirzner, 1997; Leibenstein, 1968)Market dynamics that actually explains the speed of changes in the market, also known as clockspeed (Nadkarni \& Narayanan, 2007) suggests that markets that are characterized by higher rates of unpredictability, change and uncertainty provide better opportunities for entrepreneurs by taking risk of the uncertainty(Knight, 1921). This factor is included in the GEM model as internal Market openness, based on market dynamics and market openness. Dynamism explains the pace of change in the market while openness explains the ease of entry in the market (Levie \& Autio, 2011).

Access to Physical Infrastructure

Physical infrastructure which refers to transportation facilities, land for operation, communication and telecommunication services are vital at each stage of business (Trulsson, 2002; Van de Ven, 1993). Availability and easy access to these facilities ease the process of venturing and thus enhances the entrepreneurial activity (Carter, Gartner, \& Reynolds, 1996). The availability of physical infrastructure widely varies from country to country. Some researches suggests that innovation driven economies are better in providing physical infrastructure services than factor driven economies(Bitzenis \& Nito, 2005; Ghani, Kerr, \& O'connell, 2014).

\section{Social and cultural norms}

Social and culture norms are commonly cited as drivers on entrepreneurial activity in a country. Various previous researches have attempted to measure the impact of Hofstede's cultural scales and entrepreneurship (Hayton, George, \& Zahra, 2002; Hofstede, 1980; Spencer \& Gómez, 2004; Uhlaner \&
Thurik, 2007). In the GEM model cultural context and entrepreneurial culture and social norms are dealt separately. The later covers the context level beliefs about entrepreneurship and is assumed to impact the entrepreneurial activity (Levie \& Autio, 2011). One might argue that these are universal values and cannot be changed thus does not impact policy decisions but researches support that national values, attitudes and beliefs about entrepreneurship actually change quickly than other enduring universal values (Etzioni, 1987; Inglehart, 1997). The national attitude of celebrating entrepreneurial wealth and publicity on the media increases the desirability of an individual to engage in entrepreneurial activity (P. D. Reynolds, 2012).

All the above specified entrepreneurial framework conditions are claimed in literature to support entrepreneurial activity. Policy makers are only interested in these EFCs for the ultimate objective of economic growth. The available literature on the relationship between entrepreneurial activity and economic growth is explored in the next section.

\section{Entrepreneurial activity and Economic Growth}

Economic growth and the factors influencing it has been the research area since the inception of growth models. There are many factors reported in literature that supports the economic growth of a region. Such factors include, climate, value systems, institutions, property rights, saving propensity presence of sea ports and the list goes on (Sala-iMartin, 1997; Van Stel, Carree, \& Thurik, 2005). In classical economics, entrepreneurship and new firm generation failed to be included in the list of these influencing variables unless Schumpeter(Schumpeter, 1934) and other neo classical economists claimed that entrepreneurial activity in any region is engine to economic growth and prosperity(Kirzner, 2015).

There is extensive literature review by Wong, Ho and Autio (2005) highlights the theoretical background as well as empirical studies that creates linkages between entrepreneurship and economic growth. It is suggested that entrepreneurs contribute to growth through different(Van Stel et al., 2005) behaviors that include innovation, combining resources in competitive environments. With various studies arguing that entrepreneurial activity using the "knowledge spill-over effect" and "Innovation" is resourceful for economic growth but causality between entrepreneurial activity and economic growth has yet not established significantly (Carree et al., 2007). Various empirical studies that tested these relationships have conflicting results. Research suggest that entrepreneurial activity in a country 
depends upon its GDP and varies across the stages of development not only within countries but also within regions (Carree et al., 2007). The relationship between total entrepreneurial activity and per capita income appears to be u-shaped. It means that countries with very high or very low per capita rates showed high entrepreneurial activity, whereas, countries with middle levels of per capita income showed very low entrepreneurial activity (Minniti, Bygrave, and Autio 2005). Prior researches focusing on the developed countries suggest that entrepreneurial activity may be the most significant contributor to GDP growth rate. Thus taking measures to enhance favorable conditions for knowledge transfers, intellectual property rights protection, growth of venture capitalists by policy maker can accelerate the rate of budding entrepreneurs and in turn impact the overall growth rate (Levie \& Autio, 2011; Van Stel et al., 2005; Wennekers, Van Wennekers, Thurik, \& Reynolds, 2005). Public policy makers need to pay more attention to the factors that intervene with the personal motivation factors depending upon the entrepreneurial history of a region. The u-shaped relationship brings important implication that there are different socio economic forces that play differently for rich and poorer nations (Soto, 1989; Van Stel et al., 2005; Wennekers et al., 2005). Though studies suggest that for emerging countries total entrepreneurship activity does not support GDP growth (Carree et al., 2007; Van Stel et al., 2005) but it does not mean that entrepreneurship should be discouraged in these countries. Entrepreneurship contributes to lowering unemployment and policies regarding the established firms to create spillover effects can enhance the growth of these countries (Wennekers \& Thurik, 1999).

To sum, previous studies suggest that GDP growth in emerging and developed economies may be driven by different independent variables. These variables could either be conditions at national and regional levels or the levels of entrepreneurial activity in the national economy. Different types of entrepreneurs may play a varying role in the economic development of specific countries. The variance could either be caused by the national conditions or sociocultural influences. Thus, different types of entrepreneurial activity are likely to play variable roles in the economic growth among emerging and developed countries (Soto, 1989).

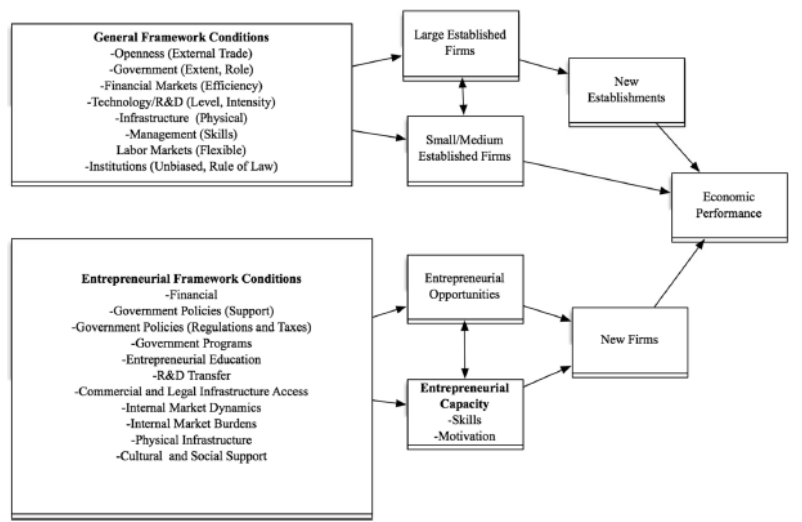

Figure 1: GEM conceptual model of business ecosystem and economic performance

\section{Data:}

\section{RESEARCH METHODOLOGY}

We have used the data from following country level sources:

1. IMF data base

2. GEM Adult population survey 2017

3. GEM National experts survey 2017

4. Global competitiveness report 2017

In our sample all the 54 countries that participated in the GEM study in 2017 are taken. The GEM economies in 2017 comprise $67.8 \%$ of the world's population and $86.0 \%$ of the world's GDP. Every year, each nation participating in the GEM cycle, surveys at least 36 key experts or informants. The National Expert Survey (NES) is like other surveys that engage expert judgments to assess specific national conditions. However, the NES emphasizes only on the environmental conditions that are expected to have a significant impact on the entrepreneurial attitudes and activities rather than on general economic features. These environmental features are then defined as GEM entrepreneurial framework conditions. Experts are asked to express their views about the most important conditions in the ecosystem that can either nurture or limit entrepreneurial activity and development in their country. In 2017, National Expert Surveys provided data on these components of the entrepreneurial framework conditions using a Likert scale of one (highly insufficient) to nine (highly sufficient).

\section{Estimation model:}

Since the data is cross section with a continuous dependent variable, we have employed OLS regression model to evaluate the impact of EFC's on Entrepreneurial activity. The following model is 
used to test the relationship between entrepreneurial framework conditions and entrepreneurial activity captured in the form of TEA:

$$
\begin{aligned}
T E A_{i}=\alpha_{0}+\alpha_{1} E F_{i}+\alpha_{2} G P S R_{i}+\alpha_{3} G P T B_{i}+\alpha_{4} G E P_{i} \\
\\
+\alpha_{5} E E_{i}+\alpha_{6} E T_{i}+\alpha_{7} R D T_{i}+\alpha_{8} C L I_{i} \\
+\alpha_{9} I M D_{i}+\alpha_{10} I M B_{i}+\alpha_{11} P I_{i} \\
+\alpha_{12} C N_{i}+\varepsilon_{i}
\end{aligned}
$$

\begin{tabular}{|c|c|}
\hline $\begin{array}{c}\text { Variable } \\
\text { name }\end{array}$ & Description \\
\hline \multicolumn{2}{|c|}{ Independent variables } \\
\hline TEA & $\begin{array}{l}\text { Total Entrepreneurial Activity- } \\
\text { The TEA index indicates the } \\
\text { percentage of the adult } \\
\text { working-age population (18- } 64 \\
\text { years old) in a country who are } \\
\text { classified as either nascent or } \\
\text { new entrepreneurs }\end{array}$ \\
\hline EEA & $\begin{array}{l}\text { Entrepreneurial employee } \\
\text { activity - EEA is the percentage } \\
\text { of the adult population aged 18- } \\
64 \text { years who, as employees, } \\
\text { have been involved in } \\
\text { entrepreneurial activities such } \\
\text { as developing or launching new } \\
\text { goods or services, or setting up } \\
\text { a new business unit, a new } \\
\text { establishment, or a subsidiary. }\end{array}$ \\
\hline SEA & $\begin{array}{l}\text { Social entrepreneurial activity- } \\
\text { SEA is the percentage of the } \\
\text { adult population aged 18-64 } \\
\text { years who are engaged in early- } \\
\text { stage entrepreneurial activities } \\
\text { with a social goal. }\end{array}$ \\
\hline
\end{tabular}

The summary list of variables is as follows:

Source

\begin{tabular}{|c|c|c|}
\hline \multicolumn{3}{|c|}{ Dependent Variables } \\
\hline$E F$ & Entrepreneurial finance & \multirow{12}{*}{$\begin{array}{l}\text { GEM } 2017 \\
\text { National } \\
\text { Experts } \\
\text { Survey } \\
\text { (NES) }\end{array}$} \\
\hline GPSR & $\begin{array}{l}\text { Government policies: support } \\
\text { and relevance }\end{array}$ & \\
\hline$G P T B$ & $\begin{array}{l}\text { Government policies: regarding } \\
\text { taxes and bureaucracy }\end{array}$ & \\
\hline$G E P$ & $\begin{array}{l}\text { Government entrepreneurship } \\
\text { programs }\end{array}$ & \\
\hline$E E$ & $\begin{array}{l}\text { Entrepreneurship education at } \\
\text { school stage }\end{array}$ & \\
\hline ET & $\begin{array}{l}\text { Entrepreneurship education at } \\
\text { post school stage and } \\
\text { entrepreneurship training }\end{array}$ & \\
\hline$R D T$ & $\begin{array}{l}\text { Research and development } \\
(\mathrm{R} \& D) \text { transfer }\end{array}$ & \\
\hline$C L I$ & $\begin{array}{l}\text { Commercial and legal } \\
\text { infrastructure }\end{array}$ & \\
\hline$I M D$ & Internal market dynamics & \\
\hline$I M B$ & $\begin{array}{l}\text { Internal market burdens or entry } \\
\text { regulation }\end{array}$ & \\
\hline$P I$ & Physical infrastructure & \\
\hline$C N$ & Cultural and social norms & \\
\hline
\end{tabular}

Adult

Population

Survey(APS)

In next stage, we have investigated whether entrepreneurial activity (TEA, SEA and EEA) impact economic growth using the model proposed by Andre' van Stel (Verheul, Stel, \& Thurik, 2006), apart from other technology, institutions and macroeconomic growth (captured by GCI). Since GCI and TEA are both structural characteristics therefore, medium term economic growth (average growth rates for last five years i.e. 2012-2017) will be taken as dependent variable. Furthermore, Gross National income per capita is used as control variable. Moreover we will include a lagged dependent variable to limit the potential impact of reverse causality.

The model can thus be explained as follows:

$$
\begin{gathered}
\triangle G D P_{i}=\alpha_{0}+\alpha_{1} T E A_{i}+\alpha_{2} G C I_{i}+\alpha_{3} \log (G N I C)_{i} \\
+\alpha_{4} \Delta G D P_{i,(t-1)}+\varepsilon_{i}
\end{gathered}
$$

Furthermore, we have also evaluated the impact of entrepreneurial activity on economic growth for developing and emerging countries separately.

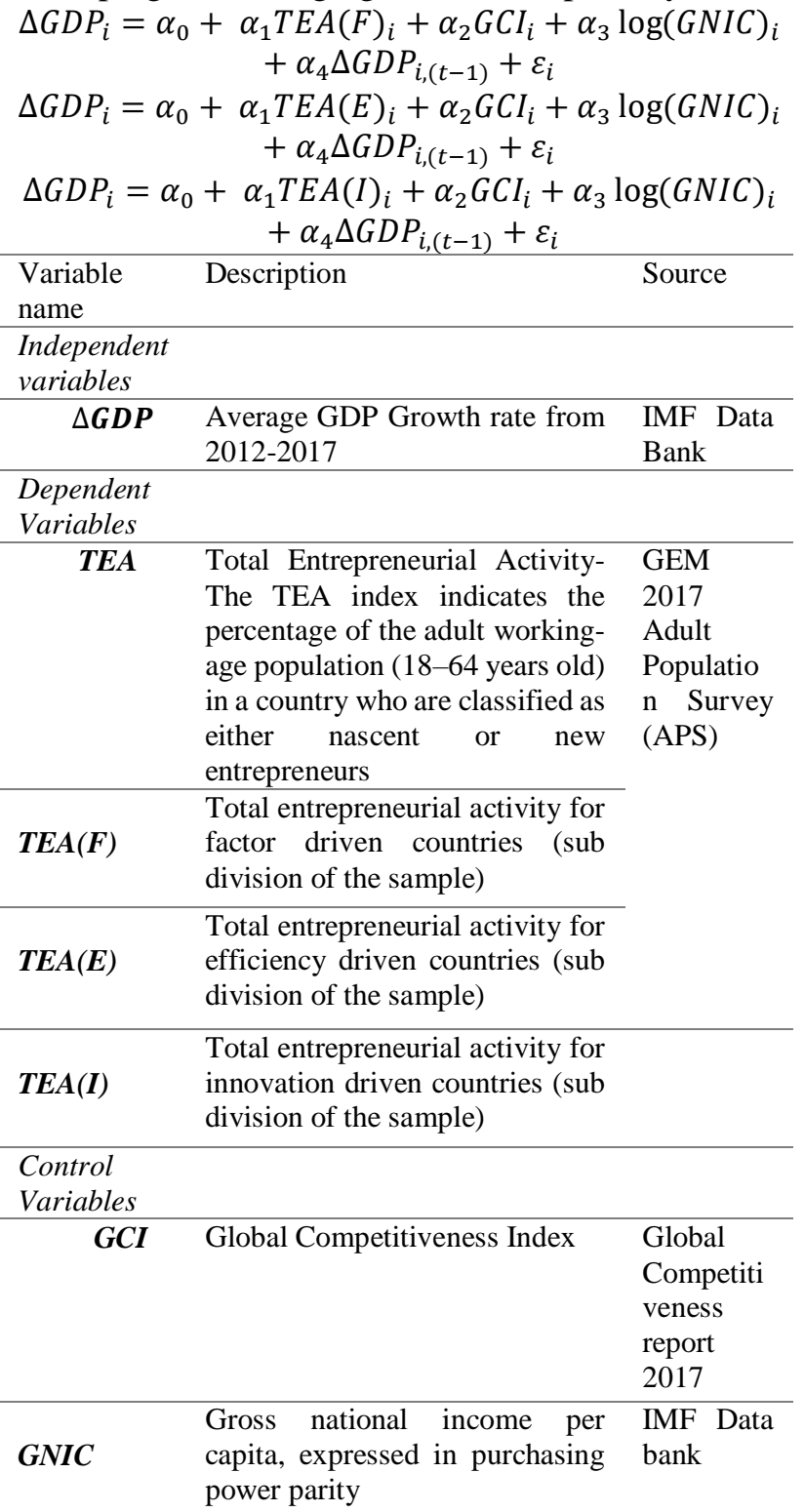




\section{$\Delta \boldsymbol{G D} \boldsymbol{P}_{\boldsymbol{i},(\boldsymbol{t}-\mathbf{1})} \quad$ Lag of dependent variable IMF Data \\ bank \\ IV. DATA ANALYSIS AND RESULTS}

Tables 1 and 2 presents our descriptive and bivariate statistics. The mean and standard deviation of the variables are indicated normality of data as none of the standard deviation is too high to make the data skewed. Correlation analysis indicates that none of the dependent variables are highly correlated thus there is no issue of multicollinearity. Collinearity diagnostics for the separate regression equations modeled are calculated using the variance inflation factor (VIF), an indicator of how much of the inflation of the standard error could be caused by collinearity. AVIF of 10 or greater is a cause for concern; all the variables in our sample showed VIF less than 10.

Table 1: Descriptive Statistics of variables

\begin{tabular}{|c|c|c|c|c|}
\hline & $\min$ & $\max$ & mean & $\mathrm{sd}$ \\
\hline dGDP & -7.46 & 8.92 & 3.158039 & 2.792069 \\
\hline TEA & 3.7 & 29.62 & 12.56412 & 6.715701 \\
\hline GCI & 3.33 & 5.81 & 4.62902 & .5978637 \\
\hline $\ln (\mathrm{GNIC})$ & 7.279319 & 11.73607 & 10.07865 & .7876627 \\
\hline $\begin{array}{l}\text { Entrepreneurial } \\
\text { Finance }\end{array}$ & 1.62 & 3.71 & 2.614706 & .4934708 \\
\hline $\begin{array}{l}\text { Government } \\
\text { Policies: Support } \\
\text { and Relevance }\end{array}$ & 1.56 & 3.75 & 2.580392 & .5360036 \\
\hline $\begin{array}{l}\text { Government } \\
\text { policies: } \\
\text { regarding taxes } \\
\text { and bureaucracy }\end{array}$ & 1.28 & 3.56 & 2.382941 & .5696571 \\
\hline $\begin{array}{l}\text { Government } \\
\text { entrepreneurship } \\
\text { programs }\end{array}$ & 1.34 & 3.63 & 2.628824 & .5469064 \\
\hline $\begin{array}{l}\text { Entrepreneurship } \\
\text { education at } \\
\text { school stage }\end{array}$ & 1.22 & 3.4 & 1.97549 & .4764213 \\
\hline $\begin{array}{l}\text { Entrepreneurship } \\
\text { education at post } \\
\text { school stage }\end{array}$ & 2.03 & 3.86 & 2.878431 & .442847 \\
\hline $\mathrm{R} \& \mathrm{D}$ transfer & 1.57 & 3.43 & 2.379608 & .4256898 \\
\hline $\begin{array}{l}\text { Commercial and } \\
\text { legal } \\
\text { infrastructure }\end{array}$ & 1.26 & 3.69 & 2.95549 & .409235 \\
\hline $\begin{array}{l}\text { Internal market } \\
\text { dynamics }\end{array}$ & 1.78 & 4.26 & 2.998824 & .5918907 \\
\hline $\begin{array}{l}\text { Internal market } \\
\text { burdens or entry } \\
\text { regulation }\end{array}$ & 1.29 & 3.73 & 2.548627 & .4067531 \\
\hline $\begin{array}{l}\text { Physical } \\
\text { infrastructure }\end{array}$ & 2.67 & 4.61 & 3.847843 & .42129 \\
\hline $\begin{array}{l}\text { Cultural and } \\
\text { social norms }\end{array}$ & 1.8 & 4.28 & 2.903922 & .5723568 \\
\hline Observations & 51 & & & \\
\hline \multicolumn{5}{|c|}{ Table 2: Correlation Table } \\
\hline & dGDP & TEA & GCI & $\ln (\mathrm{GNIC})$ \\
\hline dGDP & 1 & & & \\
\hline TEA & 0.119 & 1 & & \\
\hline GCI & -0.0666 & $-0.303^{*}$ & 1 & \\
\hline $\ln (\mathrm{GNIC})$ & -0.0485 & $-0.461^{* * *}$ & $0.758^{\text {*** }}$ & 1 \\
\hline
\end{tabular}

Table 2: Correlation Table (continue)

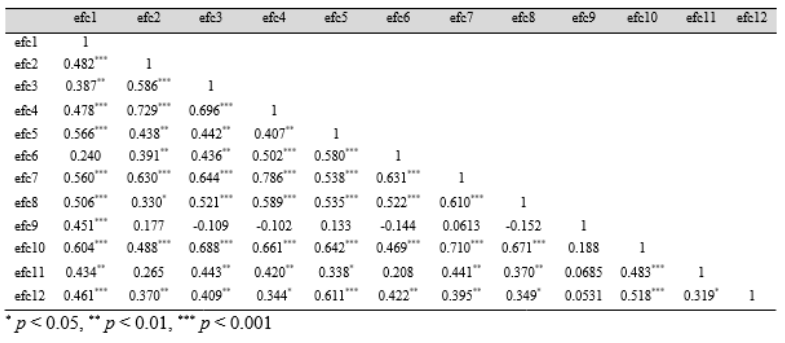

Results from the OLS model to analyze the impact of EFCs on entrepreneurial activity are presented in Table 3. Control variables are introduced to see the impact of these EFCs. The model with Established Business Operations (EBO) is giving better results and thus considered as an optimal model. Overall, significant framework conditions that positively influence entrepreneurial activity include entrepreneurship training programs at post school stage $(\beta=6.15$ and $p=0.013)$, internal market burdens $(\beta=7.147$ and $p=0.053)$, and cultural and social norms $(\beta=4.014$ and $p=0.000)$. While the factors that negatively influence entrepreneurship includes $R \& D$ transfer $(\beta=-12.03$ and $\mathrm{p}=0.000)$, internal market dynamics $(\beta=-2.87$ and $p=0.085)$ and commercial and legal infrastructure $(\beta=5.42$ and $p=0.035)$. The remaining entrepreneurial framework conditions do not significantly contributes towards entrepreneurial activity but entrepreneurship finance, government entrepreneurship programs and physical infrastructure positively influence entrepreneurship. While, government policies and entrepreneurship education at school stage are negatively influencing entrepreneurship. It may be noted that established business operations in an economy very significantly supports entrepreneurship.

Table 3: Regression Results

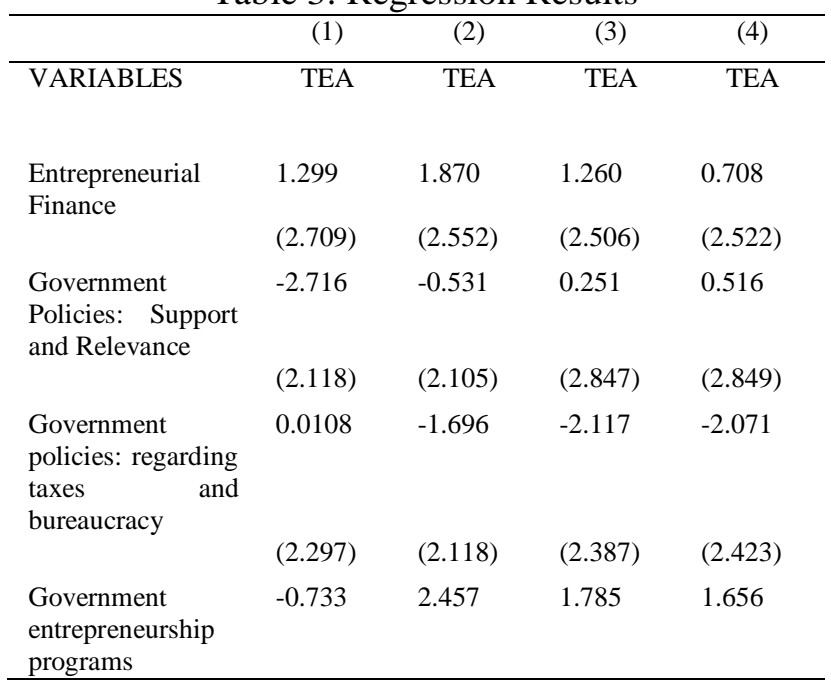




\begin{tabular}{|c|c|c|c|c|}
\hline & (2.687) & $(2.403)$ & $(2.896)$ & $(2.940)$ \\
\hline \multirow{2}{*}{$\begin{array}{l}\text { Entrepreneurship } \\
\text { education at } \\
\text { school stage }\end{array}$} & -2.920 & -2.782 & -2.837 & -2.335 \\
\hline & (1.927) & (2.096) & $(2.202)$ & $(2.420)$ \\
\hline \multirow{2}{*}{$\begin{array}{l}\text { Entrepreneurship } \\
\text { education at post } \\
\text { school stage }\end{array}$} & $10.16^{* * *}$ & $6.150^{* *}$ & $6.648^{* *}$ & $6.363^{* *}$ \\
\hline & $(2.132)$ & (2.364) & (2.659) & (2.777) \\
\hline \multirow[t]{2}{*}{$\mathrm{R} \& \mathrm{D}$ transfer } & - & - & - & - \\
\hline & $\begin{array}{l}12.10 * * * \\
(3.140)\end{array}$ & $\begin{array}{l}12.03 * * * \\
(2.731)\end{array}$ & $\begin{array}{l}13.14 * * * \\
(3.629)\end{array}$ & $\begin{array}{l}12.97 * * * \\
(3.668)\end{array}$ \\
\hline \multirow{2}{*}{$\begin{array}{l}\text { Commercial and } \\
\text { legal infrastructure }\end{array}$} & $-5.302 *$ & $-5.429 * *$ & $-4.853 *$ & $-4.627 *$ \\
\hline & $(2.921)$ & (2.479) & $(2.551)$ & (2.578) \\
\hline \multirow[t]{2}{*}{ Internal market } & -1.325 & $-2.873 *$ & $-2.743 *$ & $-2.748^{*}$ \\
\hline & (1.978) & $(1.625)$ & $(1.550)$ & (1.597) \\
\hline \multirow{2}{*}{$\begin{array}{l}\text { Internal market } \\
\text { burdens or entry } \\
\text { regulation }\end{array}$} & $8.417 * *$ & $7.147^{*}$ & $7.524 *$ & $7.461^{*}$ \\
\hline & $(3.411)$ & (3.578) & (3.937) & (3.983) \\
\hline \multirow{2}{*}{$\begin{array}{l}\text { Physical } \\
\text { infrastructure }\end{array}$} & -0.980 & 1.558 & 1.361 & 1.044 \\
\hline & $(1.883)$ & $(1.755)$ & $(1.732)$ & (1.813) \\
\hline \multirow{2}{*}{$\begin{array}{l}\text { Cultural and social } \\
\text { norms }\end{array}$} & $4.294 * * *$ & $4.014 * * *$ & $3.961 * * *$ & $3.786 * * *$ \\
\hline & $(1.258)$ & (1.011) & (1.015) & (1.029) \\
\hline \multirow[t]{2}{*}{ EBO } & & $0.496 * * *$ & $0.511 * * *$ & $0.502 * * *$ \\
\hline & & $(0.137)$ & $(0.143)$ & $(0.144)$ \\
\hline \multirow[t]{2}{*}{ GCI } & & & 1.328 & 2.228 \\
\hline & & & $(1.887)$ & (2.232) \\
\hline GNIC & & & & $\begin{array}{l}-2.81 \mathrm{e}- \\
05 \\
(5.17 \mathrm{e}- \\
05)\end{array}$ \\
\hline \multirow[t]{2}{*}{ Constant } & 12.87 & 7.620 & 2.890 & 1.307 \\
\hline & $(9.707)$ & (8.736) & (13.16) & (13.12) \\
\hline Observations & 51 & 51 & 51 & 51 \\
\hline R-squared & 0.588 & 0.671 & 0.675 & 0.677 \\
\hline
\end{tabular}

Robust standard errors in parentheses $* * * \mathrm{p}<0.01, * * \mathrm{p}<0.05, * \mathrm{p}<0.1$

\begin{tabular}{|c|c|c|c|c|c|c|c|}
\hline & (1) & (2) & (3) & (4) & (5) & (6) & (7) \\
\hline VAR & dGDP & dGDP & dGDP & dGDP & dGDP & dGDPR & dGDP \\
\hline \multirow[t]{2}{*}{ TEA } & 0.0494 & -0.457 & & & & & \\
\hline & $(0.0707)$ & (0.433) & & & & & \\
\hline \multirow[t]{2}{*}{ Tea*lemis, } & & 0.0450 & & & & & \\
\hline & & $(0.0432)$ & & & & & \\
\hline \multirow[t]{2}{*}{ GCI } & & -0.210 & & 0.184 & -0.821 & & \\
\hline & & $(0.395)$ & & $(0.330)$ & $(0.553)$ & & \\
\hline \multirow[t]{2}{*}{$\ln$ (GNIC) } & & -0.535 & & $-0.903 *$ & & $-1.703 * *$ & \\
\hline & & $(0.597)$ & & $(0.469)$ & & $(0.677)$ & \\
\hline 1(dGDE) & & $\begin{array}{l}0.766^{* * *} \\
(0.199)\end{array}$ & & $\begin{array}{l}0.679 * * * \\
0.186\end{array}$ & & & $\begin{array}{l}0.721^{* * *} \\
(0.181)\end{array}$ \\
\hline \multirow[t]{2}{*}{ teacid } & & & 0.0921 & -0.00242 & 0.0968 & 0.0748 & 0.00265 \\
\hline & & & $(0.0604)$ & $(0.0312)$ & $(0.0602)$ & $(0.0598)$ & $(0.0289)$ \\
\hline \multirow[t]{2}{*}{ tea.end } & & & $0.111^{* *}$ & -0.0242 & $0.0811^{*}$ & 0.0166 & 0.0136 \\
\hline & & & $\begin{array}{l}(0.0431) \\
0\end{array}$ & $\begin{array}{l}(0.0295) \\
0\end{array}$ & $\begin{array}{l}(0.0455) \\
0\end{array}$ & $(0.0574)$ & $(0.0223)$ \\
\hline tea.fd & & & $(0.121)$ & $(0.110)$ & $(0.121)$ & $\begin{array}{l}0.396 * * * \\
(0.138)\end{array}$ & $(0.0868)$ \\
\hline \multirow[t]{2}{*}{ Constant } & $2.538 * * *$ & $\begin{array}{l}7.335 \\
66.391\end{array}$ & $2.287 * * *$ & $9.745^{*}$ & $6.260 * *$ & $20.28^{* * *}$ & 1.015 \\
\hline & $(0.825)$ & (6.391) & $(0.736)$ & (4.907) & $(2.728)$ & $(7.247)$ & $(0.721)$ \\
\hline Observations & 51 & 51 & 51 & 51 & 51 & 51 & 51 \\
\hline$R$-squared & 0.014 & 0.739 & 0.277 & 0.787 & 0.297 & 0.378 & 0.766 \\
\hline
\end{tabular}

Results from the OLS model to analyze the impact of entrepreneurial activity on economic growth are presented in Table 4. Model 1 presents the impact of TEA on growth without any control variables. Table 2 has modeled control variables as GCI, GNIC, lagged value of the dependent variable and an interaction term. Model 3 is analyzing the impact of TEA of efficiency driven, factor driven and innovation driven economies on growth in isolation. Model 4 is analyzing the same results with control variables. The results show that TEA is not a significant factor contributing to economic growth of the country. Though TEA is positively influencing the economic growth in isolation but when analyzed with other control variables, it's negatively impacting growth. TEA for factor driven economies is negatively influencing economic growth at significant level while TEA for innovation driven and efficiency driven economies also has negative coefficients but are insignificant.

\section{CONCLUSION}

The results suggest that entrepreneurship education at post school stage, entry burdens and cultural and social norms are significant framework conditions that support entrepreneurial activity, while R\&D transfer, internal market dynamics and commercial and legal infrastructure hinders the process of entrepreneurship. Although theoretical foundations suggest that all of the EFCs should be positively influencing entrepreneurship but, since all of these are structural changes, therefore it will take time to get the impact of all these framework conditions significantly on entrepreneurship. Also established businesses are a big support factor and nascent entrepreneurs as well as established businesses go hand in hand for the economic development.

One striking result of our study is the negative impact of entrepreneurship on GDP growth. It shows that countries are not yet able to achieve the desired results of entrepreneurship as suggested by Schumpeter. The result that countries fail to benefit from entrepreneurial activity does not imply that entrepreneurship should be discouraged in these countries. Instead, it may be an indication that it will take some more time to create the Schumpeter's regime. The results of the present study provide some support for such a regime switch. Even so, the small number of observations and the specificity of the time period under investigation do not allow for too strong conclusions. 


\section{REFERENSI}

[1] Acs, Z. J., Arenius, P., Hay, M., \& Minniti, M. (2004). Global entrepreneurship monitor: London, UK y Babson Park, MA: London School y Babson College.

[2] Acs, Z. J., Desai, S., \& Hessels, J. (2008). Entrepreneurship, economic development and institutions. Small business economics, 31(3), 219-234.

[3] Acs, Z. J., \& Varga, A. (2005). Entrepreneurship, agglomeration and technological change. Small business economics, 24(3), 323-334.

[4] Aghion, P., Blundell, R., Griffith, R., Howitt, P., \& Prantl, S. (2006). The effects of entry on incumbent innovation and productivity: National Bureau of Economic Research.

[5] Audretsch, D. B., Grilo, I., \& Thurik, A. R. (2007). Explaining entrepreneurship and the role of policy: a framework. The handbook of research on entrepreneurship policy, 1-17.

[6] Audretsch, D. B., \& Lehmann, E. E. (2005). Does the knowledge spillover theory of entrepreneurship hold for regions? Research Policy, 34(8), 1191-1202.

[7] Baumol, W. J. (1990). Sir John versus the Hicksians, or theorist malgré lui? Journal of economic Literature, 1708-1715.

[8] Bitzenis, A., \& Nito, E. (2005). Obstacles to entrepreneurship in a transition business environment: the case of Albania. Journal of Small Business and Enterprise Development, 12(4), 564-578.

[9] Blau, D. M. (1987). A time-series analysis of self-employment in the United States. Journal of political economy, 95(3), 445-467.

[10] Bosma, N., Sanders, M., \& Stam, E. (2018). Institutions, entrepreneurship, and economic growth in Europe. Small business economics, 117.

[11] Brenner, R. (1992). Entrepreneurship and business ventures in the new commonmwealth. Journal of Business Venturing, 7(6), 431-439.

[12] Brown, T. C., \& Hanlon, D. (2016). Behavioral criteria for grounding entrepreneurship education and training programs: A validation study. Journal of Small Business Management, 54(2), 399-419.

[13] Bruton, G. D., Ketchen, D. J., \& Ireland, R. D. (2013). Entrepreneurship as a solution to poverty. Journal of Business Venturing, 28(6), 683-689.

[14] Bullough, A., De Luque, M. S., Abdelzaher, D., \& Heim, W. (2015). Developing women leaders through entrepreneurship education and training. The Academy of Management Perspectives, 29(2), 250-270.

[15] Carree, M., Van Stel, A., Thurik, R., \& Wennekers, S. (2007). The relationship between economic development and business ownership revisited. Entrepreneurship \& regional development, 19(3), 281-291.

[16] Carter, N. M., Gartner, W. B., \& Reynolds, P. D. (1996). Exploring start-up event sequences. Journal of Business Venturing, 11(3), 151-166.

[17] Choo, S., \& Wong, M. (2006). Entrepreneurial intention: triggers and barriers to new venture creations in Singapore. Singapore management review, 28(2), 47.

[18] Clarysse, B., \& Bruneel, J. (2007). Nurturing and growing innovative start-ups: the role of policy as integrator. $R \& d$ Management, $37(2)$, 139-149.

[19] DeTienne, D. R., \& Chandler, G. N. (2004). Opportunity identification and its role in the entrepreneurial classroom: A pedagogical approach and empirical test. Academy of management learning \& education, 3(3), 242257.

[20] Edelman, L. F., Manolova, T. S., \& Brush, C. G. (2008). Entrepreneurship education: Correspondence between practices of nascent entrepreneurs and textbook prescriptions for success. Academy of Management Learning \& Education, 7(1), 56-70.

[21] Etzioni, A. (1987). Entrepreneurship, adaptation and legitimation: a macro-behavioral perspective. Journal of Economic Behavior \& Organization, 8(2), 175-189.

[22] Fischer, E., \& Reuber, A. R. (2003). Support for rapid-growth firms: a comparison of the views of founders, government policymakers, and private sector resource providers. Journal of small business management, 41(4), 346-365.

[23] Ghani, E., Kerr, W. R., \& O'connell, S. (2014). Spatial determinants of entrepreneurship in India. Regional Studies, 48(6), 1071-1089.

[24] Hayton, J. C., George, G., \& Zahra, S. A. (2002). National culture and entrepreneurship: A review of behavioral research. Entrepreneurship theory and practice, 26(4), 33-52. 
[25] Hechavarría, D. M., \& Ingram, A. E. (2018). Entrepreneurial ecosystem conditions and gendered national-level entrepreneurial activity: a 14-year panel study of GEM. Small business economics, 1-28.

[26] Hofstede, G. (1980). Motivation, leadership, and organization: do American theories apply abroad? Organizational dynamics, 9(1), 42-63.

[27] Honig, B. (2004). Entrepreneurship education: Toward a model of contingency-based business planning. Academy of management learning \& education, 3(3), 258-273.

[28] Inglehart, R. (1997). Modernization and postmodernization: Cultural, economic, and political change in 43 societies: Princeton University Press.

[29] Keuschnigg, C., \& Nielsen, S. B. (2004). Startups, venture capitalists, and the capital gains tax. Journal of Public Economics, 88(5), 1011-1042.

[30] Kirzner, I. M. (1997). Entrepreneurial discovery and the competitive market process: An Austrian approach. Journal of economic Literature, 35(1), 60-85.

[31] Kirzner, I. M. (2015). Competition and entrepreneurship: University of Chicago press.

[32] Klepper, S., \& Sleeper, S. (2005). Entry by spinoffs. Management science, 51(8), 12911306.

[33] Knight, F. H. (1921). Risk, uncertainty and profit. New York: Hart, Schaffner and Marx.

[34] Kouriloff, M. (2000). Exploring perceptions of a priori barriers to entrepreneurship: a multidisciplinary approach. Entrepreneurship theory and practice, 25(2), 59-80.

[35] Lee, S.-H., Yamakawa, Y., Peng, M. W., \& Barney, J. B. (2011). How do bankruptcy laws affect entrepreneurship development around the world? Journal of Business Venturing, 26(5), 505-520.

[36] Leibenstein, H. (1968). Entrepreneurship and development. The American economic review, 58(2), 72-83.

[37] Levie, J., \& Autio, E. (2008). A theoretical grounding and test of the GEM model. Small business economics, 31(3), 235-263.

[38] Levie, J., \& Autio, E. (2011). Regulatory burden, rule of law, and entry of strategic entrepreneurs: An international panel study. Journal of Management Studies, 48(6), 13921419.

[39] Markman, G. D., Gianiodis, P. T., Phan, P. H., \& Balkin, D. B. (2004). Entrepreneurship from the ivory tower: Do incentive systems matter? The Journal of Technology Transfer, 29(3-4), 353-364.

[40] Martin, B. C., McNally, J. J., \& Kay, M. J. (2013). Examining the formation of human capital in entrepreneurship: A meta-analysis of entrepreneurship education outcomes. Journal of Business Venturing, 28(2), 211-224.

[41] McMullen, J. S., Bagby, D., \& Palich, L. E. (2008). Economic freedom and the motivation to engage in entrepreneurial action. Entrepreneurship theory and practice, 32(5), 875-895.

[42] Metcalfe, J. S. (2004). The entrepreneur and the style of modern economics. Journal of Evolutionary Economics, 14(2), 157-175.

[43] Mullins, J. W., \& Forlani, D. (2005). Missing the boat or sinking the boat: A study of new venture decision making. Journal of Business Venturing, 20(1), 47-69.

[44] Nadkarni, S., \& Narayanan, V. K. (2007). Strategic schemas, strategic flexibility, and firm performance: The moderating role of industry clockspeed. Strategic management journal, 28(3), 243-270.

[45] North, D. C. (1994). Economic performance through time. The American economic review, 84(3), 359-368.

[46] Peterman, N. E., \& Kennedy, J. (2003). Enterprise education: Influencing students' perceptions of entrepreneurship. Entrepreneurship theory and practice, 28(2), 129-144.

[47] Reynolds, P., Bosma, N., Autio, E., Hunt, S., De Bono, N., Servais, I., . . Chin, N. (2005). Global entrepreneurship monitor: Data collection design and implementation 1998-2003. Small business economics, 24(3), 205-231.

[48] Reynolds, P. D. (2012). Entrepreneurship in developing economies: The bottom billions and business creation. Foundations and Trends ${ }^{\circledR}$ in Entrepreneurship, 8(3), 141-277.

[49] Robertson, M., Collins, A., Medeira, N., \& Slater, J. (2003). Barriers to start-up and their effect on aspirant entrepreneurs. Education+ Training, 45(6), 308-316.

[50] Ruef, M. (2005). Origins of organizations: The entrepreneurial process Entrepreneurship (pp. 63-100): Emerald Group Publishing Limited.

[51] Sala-i-Martin, X. X. (1997). I just ran four million regressions: National Bureau of Economic Research. 
[52] Schumpeter. (1934). The theory of Economic Development. Harvard University Press.

[53] Schumpeter, J. (1942). Capitalism, Socialism and Democracy, New York: Harper, 1975.

[54] Shane, S., \& Cable, D. (2002). Network ties, reputation, and the financing of new ventures. Management science, 48(3), 364-381.

[55] Sobel, R. S. (2008). Testing Baumol: Institutional quality and the productivity of entrepreneurship. Journal of Business Venturing, 23(6), 641-655.

[56] Soto, H. d. (1989). The other path: the invisible revolution in the Third World. New York.

[57] Spencer, J. W., \& Gómez, C. (2004). The relationship among national institutional structures, economic factors, and domestic entrepreneurial activity: a multicountry study. Journal of Business Research, 57(10), 10981107.

[58] Stevenson, L., \& Lundström, A. (2007). Dressing the emperor: the fabric of entrepreneurship policy. Handbook of research on entrepreneurship policy, 94-129.

[59] Storey, D. J. (2003). Entrepreneurship, small and medium sized enterprises and public policies Handbook of entrepreneurship research (pp. 473-511): Springer.

[60] Suzuki, K.-i., Kim, S.-H., \& Bae, Z.-T. (2002). Entrepreneurship in Japan and Silicon Valley: a comparative study. Technovation, 22(10), 595606.

[61] Trulsson, P. (2002). Constraints of growthoriented enterprises in the southern and eastern African region. Journal of Developmental Entrepreneurship, 7(3), 331.

[62] Uhlaner, L., \& Thurik, R. (2007). Postmaterialism influencing total entrepreneurial activity across nations. Journal of Evolutionary Economics, 17(2), 161-185.
[63] Van de Ven, H. (1993). The development of an infrastructure for entrepreneurship. Journal of Business Venturing, 8(3), 211-230.

[64] Van Stel, A., Carree, M., \& Thurik, R. (2005). The effect of entrepreneurial activity on national economic growth. Small business economics, 24(3), 311-321.

[65] Vanevenhoven, J. (2013). Advances and challenges in entrepreneurship education. Journal of Small Business Management, 51(3), 466-470.

[66] Verheul, I., Stel, A. V., \& Thurik, R. (2006). Explaining female and male entrepreneurship at the country level. Entrepreneurship and regional development, 18(2), 151-183.

[67] Volery, T., Doss, N., Mazzarol, T., \& Thein, V. (1997). Triggers and Barriers Affecting Entrepreneurial Intentionality: The Case of Western Australian Nascente Entrepreneurs. Journal of Enterprising Culture, 5(03), 273291.

[68] Welter, F. (2011). Contextualizing entrepreneurship - conceptual challenges and ways forward. Entrepreneurship theory and practice, 35(1), 165-184.

[69] Wennekers, S., \& Thurik, R. (1999). Linking entrepreneurship and economic growth. Small business economics, 13(1), 27-56.

[70] Wennekers, S., Van Wennekers, A., Thurik, R., \& Reynolds, P. (2005). Nascent entrepreneurship and the level of economic development. Small business economics, 24(3), 293-309.

[71] Wong, P. K., Ho, Y. P., \& Autio, E. (2005). Entrepreneurship, innovation and economic growth: Evidence from GEM data. Small business economics, 24(3), 335-350. 